\author{
dr hab. inż. Anna MĘ்̇ YK \\ Wydział Transportu i Elektrotechniki, Uniwersytet Technologiczno-Humanistyczny \\ im. K. Pułaskiego w Radomiu \\ e-mail: a.mezyk@uthrad.pl
}

\author{
dr hab. Stanisława ZAMKOWSKA \\ Podkarpacka Szkoła Wyższa im. bł. ks. Władysława Findysza w Jaśle \\ e-mail: s_zamkowska@poczta.onet.pl
}

DOI: $10.15290 /$ ose.2016.06.84.07

\title{
TENDENCJE ROZWOJOWE W TRANSPORCIE POLSKIM NA TLE WYZWAŃ STAWIANYCH PRZEZ GOSPODARKĘ
}

\begin{abstract}
Streszczenie
Transport, ze względu na jego rolę w obsłudze potrzeb przewozowych społeczeństwa, jest kluczowym czynnikiem umożliwiajacym funkcjonowanie gospodarek i rozwój globalnej współpracy. Sprawna obsługa tych wzrastających i zmieniających się potrzeb jest zatem jednym z istotnych warunków wzrostu efektywności gospodarki. W artykule przedstawiono najważniejsze czynniki wpływające współcześnie na zmiany potrzeb przewozowych, do których należą: postęp globalizacji i integracji, rozwój gospodarki elektronicznej i logistyki, koncentracja życia gospodarczego i społecznego w miastach oraz pojawienie się różnego rodzaju zagrożeń. W artykule zawarto także syntetyczną charakterystykę statystyczną rozwoju transportu w Polsce po wejściu do Unii Europejskiej. Jedną z głównych tendencji wyróżniającą rozwój polskiego transportu w tym okresie jest zwiększenie udziału transportu samochodowego w rynku i zdecydowany wzrost jego konkurencyjności międzynarodowej, co umiejscawia transport wśród najważniejszych działów polskiej gospodarki. Jednak dalsze efektywne funkcjonowanie transportu jako systemu wspierającego rozwój gospodarki wymaga poniesienia znaczących nakładów na jego wyposażenie techniczne i infrastrukturę.

Celem artykułu jest ukazanie tendencji rozwojowych w transporcie polskim na tle wyzwań stawianych przez gospodarkę.
\end{abstract}

Słowa kluczowe: potrzeby przewozowe, globalizacja, e-handel, logistyka, zagrożenia, rozwój transportu

\section{DEVELOPMENT TRENDS IN POLISH TRANSPORT AND ECONOMIC CHALLENGES}

\section{Summary}

Because of its vital role in society, transport is a key factor enabling the functioning of economies and the development of global cooperation. Efficient servicing of these growing and changing needs is, therefore, one of the crucial conditions for increased economic efficiency. The paper presents the most important factors influencing contemporary changes in transport needs, which include: the progress of globalization and integration, the development of e-commerce and logistics, the concentration of economic and social life in the cities and the emergence of various risks. The paper also contains a synthetic statistical profile of transport 
development in Poland after joining the European Union. One of the main trends in the development of Polish transport during this period is the growing share of road transport in the transport market, and a significant increase in its international competitiveness, which places it among the most important sectors of the Polish economy. However, further effective functioning of transport as a stimulus for economic development requires substantial expenditure on its technical equipment and infrastructure. The author aims to show the development trends in the Polish transport against the background of the challenges posed by the economy.

Key words: transport needs, globalization, e-commerce, logistics, threats, transport development

JEL: L91

\section{Wstęp}

Wraz z rozwojem cywilizacji oraz pogłębiającym się podziałem i specjalizacją pracy na przestrzeni wieków rozwijały się również różne formy i techniki transportu. Wynika to $z$ podstawowej roli transportu, jaką jest przemieszczanie ładunków i ludzi na skutek zgłaszanych potrzeb przewozowych. Potrzeby te są odzwierciedlane przez takie czynniki, jak: popyt na przewozy, kierunki geograficzne przewozu i wymagania związane z jakością usług transportowych. Wszystkie z wymienionych czynników ulegają istotnym zmianom w ostatnim okresie i, co charakterystyczne, zmiany te przebiegają coraz bardziej dynamicznie i nie zawsze są przewidywalne. Na wielkość popytu na przewozy i realizowane kierunki geograficzne transportu oddziałują zmiany zarówno w zasięgu współpracy międzynarodowej, w organizacji procesów gospodarczych, jak i w sposobie życia ludności. Wzrost aktywności gospodarczej i coraz większa otwartość różnych państw i regionów, rosnące znaczenie handlu międzynarodowego i turystyki, a także wzrost liczby ludności i migracje sa głównymi czynnikami intensyfikacji potoków pasażerów i towarów. Koszt usługi transportowej jest składnikiem kosztu każdego dobra i usługi, co oznacza, że transport ma duży wpływ na koszty logistyczne i ogólny koszt produkcji. Wzrost efektywności transportu jest zatem kluczowym czynnikiem poprawy efektywności i konkurencyjności całej gospodarki.

Celem artykułu jest ukazanie tendencji rozwojowych w transporcie polskim na tle wyzwań stawianych przez gospodarkę.

\section{Zmiany potrzeb przewozowych wynikające ze zmian politycznych i gospodarczo-społecznych}

\subsection{Wpływ procesów integracyjnych i globalizacji na zmiany w transporcie}

Najważniejsze zmiany w funkcjonowaniu społeczeństw w ostatnich dekadach wnosi postępująca globalizacja. Według definicji przyjętej przez Organizację Współpracy Gospodarczej i Rozwoju (OECD): globalizacja jest procesem polegajacym na tym, ze rynki i produkcja w poszrzególnych krajach sq od siebie bardziej zależne wskutek. wrrastajacej dynamiki handlu dobrami i ustugami oraz dynamiki prsyptywn kapitatu i technologii [Wołodkiewicz-Donimirski, 2000]. 
Zmiany uwarunkowań gospodarczych zachodzące na świecie pociagają za sobą szereg istotnych przeobrażeń w funkcjonowaniu europejskiego i polskiego transportu wraz z wejściem Polski do Unii Europejskiej w 2004 roku. Transport polski musi wpisać się w reguły wspólnego rynku europejskiego i zarazem rynku globalnego. Pod wpływem globalizacji gospodarki i integracji europejskiej sa generowane nowe potrzeby i nowe wymagania w stosunku do krajowego systemu transportowego. Jednocześnie zmiany te stworzyły potrzebę ponownego określenia miejsca poszczególnych gałęzi transportu w obsłudze potrzeb przewozowych gospodarki i społeczeństwa.

Głównym przejawem globalizacji jest otwartość państw i gospodarek. Zawierane między różnymi krajami i organizacjami międzynarodowymi porozumienia polityczne i gospodarcze, wprowadzające nowe rozwiązania prawne, organizacyjne i ekonomiczne, a także istniejący poziom techniki powoduja dynamiczny wzrost zasięgu przemieszczeń osób i towarów, rozciagający się na obszar całego świata. Rosną również oczekiwania klientów dotyczące: szybkości, terminowości i niezawodności dostaw, natomiast to decyduje o bardzo wysokich wymaganiach wobec organizacji transportu i konieczności jego dyspozycyjności przez całą dobę.

Globalizacji podlega przede wszystkim światowa gospodarka. W produkcji dóbr materialnych procesy zaopatrzenia, produkcji i dystrybucji w coraz większym stopniu mają zasięg światowy. Poszukiwanie nowych rynków zbytu oraz zaopatrzenia w surowce, tańszych sposobów produkcji wywołuje potrzebę międzynarodowych powiązań gospodarczych i wymiany handlowej. Dużego znaczenia nabiera możliwość wykorzystania różnic kosztów produkcji w poszczególnych krajach. Zatem, oprócz globalizacji rynków, równocześnie występuje globalizacja całych gałęzi przemysłu (sektorów) i globalizacja firm, czego przykładem sa globalne korporacje i koncerny przemysłowe. Prowadzi to do zacieśnienia powiązań handlowych, inwestycyjnych i umownych między gospodarkami różnych krajów. Istotnym więc wymogiem właściwej współpracy międzynarodowej i sprawnego funkcjonowania gospodarki światowej są wydajne systemy transportowe.

W przewozach międzykontynentalnych osób i przesyłek drobnych szczególną rolę odgrywa transport lotniczy, zaś w dostawach masowych ładunków - transport morski, a w niektórych relacjach również transport kolejowy (np. Europa - regiony Azji). Wzrost potrzeb w zakresie mobilności i transportu w skali globalnej wymusza tworzenie nowych konstrukcji samolotów i statków o znacznie większych gabarytach niż dotychczas, bardziej ekonomicznych, odpowiadających preferencjom klientów, jak również spełniających wymagania ekologiczne.

Zgodnie z najnowszą globalną prognozą rynkowa, przygotowana przez producenta samolotów Airbus, w ciagu następnych 20 lat (2016-2035) ruch lotniczy będzie rósł średnio w tempie 4,5\% rocznie. Globalna flota samolotów powiększy się dwukrotnie do prawie 40 tys. statków powietrznych, z czego jedna trzecia to będą modele paliwooszczędne. Nowe samoloty mają charakteryzować się większą pojemnością i ładownościa. Przewiduje się, że w tym okresie zapotrzebowanie na samoloty towarowe o ładowności ponad 10 ton wyniesie około 650 sztuk. Motorem napędowym wzrostu ruchu lotniczego będzie urbanizacja i rosnąca zamożność na rynkach azjatyckich, szczególnie w Chinach 
i Indiach. Według cytowanej prognozy, w ciagu najbliższych10 lat rynek wewnętrzny w Chinach stanie się największym rynkiem lotniczym na świecie [Hryniewicz, 2016].

W rozwoju sektora lotniczego upatruje się możliwość zdynamizowania globalizacji w wielu dziedzinach działalności, ti.: gospodarczej, handlowej i turystycznej. Coraz większą rolę na rynku usług lotniczych odgrywają przewoźnicy niskokosztowi, których model działalności stwarza sprzyjające warunki do wzrostu ich udziału nie tylko w relacjach regionalnych, ale także w rynku komunikacji międzyregionalnej.

Wskazane tendencje obserwuje się również na rynku polskim, szczególnie w zakresie przewozów pasażerskich. Liczba pasażerów obsłużonych w I kwartale 2016 była większa o $16 \%$ niż w analogicznym okresie roku ubiegłego. Obecnie przewoźnicy niskokosztowi posiadają $66 \%$ udziału w międzynarodowych przewozach regularnych [Konwicki, 2016].

Gorzej wygląda sytuacja w Polsce w odniesieniu do przewozów lotniczego cargo. Globalny rynek lotniczy przewozu ładunków rozwija się niezwykle dynamicznie. W 2000 roku na świecie samolotami przewieziono ponad $30 \mathrm{mln}$ ton ładunków, a praca przewozowa wyniosła $118 \mathrm{mld} \mathrm{tkm}$. Natomiast w roku 2014 przewieziono $50 \mathrm{mln}$ ton przy $194 \mathrm{mld}$ tkm pracy przewozowej. Polski rynek lotniczy cargo stanowił zaledwie 1\% europejskiego rynku cargo i były to przewozy rzędu 130 tys. ton rocznie. Wynika to z charakteru polskiej produkcji eksportowej, która bardziej nadaje się do przewozu drogą lądową lub wodna, jak również ze słabości połączeń lotniczych i infrastruktury [Urbaniak, 2016].

W obsłudze połączeń międzykontynentalnych będzie także wzrastać udział transportu morskiego i równocześnie transportu kolejowego w relacji Europa - Azja. Główne szlaki morskie łączą ze sobą m.in. obszary wydobycia surowców mineralnych (Australia, Bliski Wschód, Chiny) z obszarami ich przetwarzania (Azja Wschodnia i Południowa, Europa, USA). Połączenie i modernizacja sieci kolejowej między Europą a Azją pozwoliłoby na skrócenie czasu transportu towarów ponad dwukrotnie w stosunku do drogi morskiej. W ostatnim okresie uruchomiono bezpośrednie pociagi kontenerowe pomiędzy Polską a Chinami oraz Łotwą a Chinami. Celem dalszych działań, obejmujących modernizację linii kolejowych, jest skrócenie czasu przewozu towarów z Chin do Środkowej Europy (11 tys. km) do 10 dni.

Jednocześnie jest zauważalny pewien wzrost znaczenia transportu morskiego w Polsce. W pierwszym półroczu 2016 roku odnotowano wzrost przeładunków w portach w Szczecinie i Świnoujściu, przede wszystkim dzięki wzrostowi: przeładunków kontenerów, dostawom paliwa LNG do terminalu w Świnoujściu i uruchomieniu przeładunków zbóż w porcie szczecińskim [Sobecki, 2016].

\subsection{Wpływ rozwoju logistyki i e-handlu na działalność transportu}

Kolejnym elementem wspólistniejącym z globalizacją jest rozwój logistycznych koncepcji organizacji produkcji, które wykorzystują rozwój technologii informatycznych. Nowe zasady organizacji procesów produkcyjnych, np. just in time, głównie w relacjach 
B2B, oraz zmiany w strukturach łańcuchów dostaw (np. koncentracja międzynarodowego handlu w centrach logistycznych i terminalach), wymagają większej elastyczności i koordynacji poszczególnych gałęzi transportu. Producenci potrzebują systemów dostaw skorelowanych z wymaganiami klientów, które zapewnią im dostarczenie właściwych towarów do właściwych miejsc i w odpowiednim czasie.

Istotnym czynnikiem generującym coraz większe potrzeby przewozowe jest stale rosnąca liczba mieszkańców i innych podmiotów funkcjonujących w miastach, wymagających zaspokojenia ich potrzeb. Znaczna część ludności napływa do miast ze względu na to, że są one ośrodkami rozwoju: zakładów przemysłowych, handlu, nauki, rozrywki $\mathrm{i}$ innych dziedzin. Co tydzień liczba ludności miejskiej na świecie powiększa się o $1 \mathrm{mln}$. Współcześnie ponad połowa światowej populacji żyje w miastach i na jego obrzeżach, a przewiduje się, że w 2050 roku blisko 66\% ludności świata będzie żyło i mieszkało w miastach. Miasta sa miejscem skoncentrowanej produkcji przemysłowej, co stwarza zapotrzebowanie na przewozy ładunków - surowców, półproduktów, a także wyrobów gotowych i odpadów przemysłowych. Jak podaje Komisja Europejska, w miastach Unii Europejskiej mieszka obecnie 70\% ludności i powstaje w nich blisko 80\% PKB [Plan utworzenia jednolitego europejskiego obszaru transportu..., 2011].

Znamiennym symptomem zmian, wykorzystujących nowe technologie, jest rozwój e-handlu w różnych relacjach pomiędzy producentami a konsumentami, tj.: B2C, B2B, C2C, C2B. Jego konsekwencją są zasadnicze zmiany w systemach zamówień i dostaw towarów. Zwiększenie obrotów w e-handlu i wzrost popularności aukcji internetowych przyczyniają się do wzrostu udziału ładunków drobnicowych w ogólnej masie ładunkowej i zmniejszenia wielkości pojedynczego ładunku. Jest to istotny impuls do rozwoju rynku usług kurierskich, w tym przesyłek ekspresowych. Dodatkowo rozwój e-handlu ułatwia elektroniczna bankowość i zmniejszenie kosztów transportu na dalekie odległości. Rozwój e-handlu nie eliminuje transportu, a wręcz przeciwnie, oddziałuje na jego zwiększoną aktywność. Pojawiają się nowe ładunki wymagające krótkiego czasu dostawy.

Wzrost przewozów generowany przez e-handel ma miejsce zwłaszcza dzięki wykorzystaniu pojazdów samochodowych, co wiąże się z: rozproszeniem odbiorców i nadawców ładunków, dostępnością infrastruktury transportu i największą elastycznością transportu samochodowego w stosunku do innych możliwych do wykorzystania środków transportu. Niektóre zmiany są generowane przez ,gospodarkę 24-godzinną”. W gospodarce globalnej rynki są otwarte non stop. Zwiększony popyt wymaga produkcji ciagłej, a handel globalny pracy przez cały czas. Ma to oczywisty wpływ na transport i łańcuchy dostaw. Coraz więcej punktów handlowych, lecz zarazem rozrywkowych i sportowych (fitness) funkcjonuje w systemie 24/7, jak również następuje wydłużanie godzin otwarcia galerii i centrów zakupowych. W konsekwencji często są wymagane kilkukrotne dostawy do zakładów produkcyjnych i punktów handlowych w ciągu doby. 


\subsection{Rozwój turystyki i migracje a wzrost potrzeb przewozowych ludności}

W dobie globalizacji coraz większego znaczenia nabiera rozwój turystyki, zarówno ze względu na możliwości otwarcia nowych i wielkich przestrzeni, obejmujących różne kraje i kontynenty, jak i ze względu na bogacenie się społeczeństw i wzrastający udział usług w strukturze konsumpcji. Coraz większą rolę w konsumpcji usług odgrywają właśnie usługi turystyczne. Ponadto, wiele nowych, do niedawna jeszcze nieodkrytych lub niedostępnych, regionów świata upatruje w rozwoju turystyki szans na rozwój gospodarczy i możliwości wzrostu swojej pozycji konkurencyjnej. W wielu sytuacjach zwiększenie konkurencyjności regionów dzięki rozwojowi turystyki staje się podstawą do bogacenia się: przedsiębiorstw, samorządów i lokalnych społeczności. Turystyka przyczynia się również do tworzenia nowych miejsc pracy i wzrostu zatrudnienia. Czynione sa zatem starania o pozyskanie nie tylko turystów, lecz zarazem inwestorów w skali międzynarodowej, w celu rozbudowy infrastruktury: turystycznej, komunikacyjnej, technicznej i usługowej. Jednocześnie zauważa się coraz większą otwartość Europy na realizację celów turystycznych w skali światowej. Obsługa potrzeb turystycznych stanowi kolejne uwarunkowanie dotyczące potrzeb w zakresie mobilności i kształtowania nowych powiązań transportowych w skali globalnej.

Ważnym czynnikiem, kształtującym potrzeby turystyczne, są wyjazdy w poszukiwaniu pracy. W wielu krajach bezrobocie osiaga wysoki poziom, co zmusza znaczną liczbę osób, głównie młodych, do wyjazdów zarobkowych za granicę, w tym na inne kontynenty. Taka sytuacja rodzi nowe potrzeby w zakresie mobilności związane z zapewnieniem obsługi tych wyjazdów oraz powrotów, a także z łączeniem rodzin. Rosnąca liczba migrantów zarobkowych i uchodźców stawia nowe wyzwania, zwłaszcza dla transportu miejskiego. Przewiduje się, że 62\% światowej populacji do roku 2035 będzie mieszkać w miastach. W konsekwencji oznacza to wzrost przewozów miejskich i aglomeracyjnych.

Obszarem usługowym, który obecnie rozwija się na skalę międzynarodową i zbliża do siebie różne kraje świata, jest organizacja masowych imprez o znaczeniu światowym. Natomiast te nie tylko generuja potrzeby w zakresie mobilności i transportu, wiążą się równocześnie z wysokim poziomem obsługi transportowej i logistycznej. Wszystkie imprezy mega events są trwałym składnikiem kultury, mającym wpływ na ekonomię i wiążącym się z ogromnymi przedsięwzięciami materialnymi i organizacyjnymi. Wysokie oczekiwania pod względem poziomu obsługi tychże imprez wymagaja znaczącego zaangażowania środków i ludzi na rzecz ich przygotowania oraz przebiegu, w tym zapewnienia właściwej organizacji: mobilności osób, transportu towarów i bezpieczeństwa.

Z kolei, ograniczenia ekologiczne wypromowały zasadę zrównoważonego rozwoju, która staje się istotnym czynnikiem determinującym rozwój wszelkich dziedzin działalności człowieka, a przede wszystkim transportu - jako jednego z największych ,trucicieli” środowiska. W Unii Europejskiej szczególnie kładzie się nacisk na zaspokojenie potrzeb gospodarki i społeczeństwa, przy jak najmniejszym negatywnym wpływie transportu na środowisko naturalne. 
Procesy integracyjne w Europie i wzrost gospodarki europejskiej wymagają także coraz większego zapotrzebowania na usługi transportowe oraz zmian w kierunku tworzenia jednolitego europejskiego rynku transportowego. Nowy model systemu transportowego powinien zapewniać wysoką jakość i wydajność transportu, w tym w przewozach na dalekie odległości. Stąd też jednym z ważnych celów polityki Unii Europejskiej jest zagwarantowanie wysokiego poziomu mobilności ludzi i towarów, przy jednoczesnym doborze środków transportu przyjaznych dla środowiska.

Wszystkie wymienione czynniki wywieraja wpływ na funkcjonowanie polskiej gospodarki i polskiego transportu. W analizowanym okresie 2004-2014 szczególne znaczenie miało wejście Polski do Unii Europejskiej.

\section{Charakterystyka statystyczna zmian na rynku transportowym Polski po wejściu do Unii Europejskiej}

\subsection{Zmiana wielkości przewozów}

Skutki gospodarcze akcesji Polski do Unii Europejskiej są znane i szeroko opisywane, w tym miejscu autorki miały na celu uwypuklenie jej transportowych konsekwencji. Impuls do rozwoju gospodarczego, jakim był dostęp do dużego rynku europejskiego, jak również pozyskanie znaczących środków finansowych na rozwój infrastruktury ekonomicznej spowodowały znaczący wzrost: obrotów handlowych, masy przewożonych ładunków i odległości przewozu. Dane liczbowe charakteryzujące ten proces zostały przedstawione w tabelach: 1.-6.

TABELA 1.

Obroty handlowe i główni partnerzy Polski w latach 2005-2014

\begin{tabular}{|c|c|c|c|c|c|c|c|c|}
\hline \multirow{3}{*}{$\begin{array}{l}\text { Lata } \\
2005\end{array}$} & \multirow{2}{*}{\multicolumn{2}{|c|}{$\begin{array}{c}\text { Ogółem } \\
\text { (w mln dol. USA) }\end{array}$}} & \multicolumn{6}{|c|}{ Główni partnerzy } \\
\hline & & & \multirow{2}{*}{$\begin{array}{c}\text { kraj } \\
\text { Niemcy }\end{array}$} & \multirow{2}{*}{$\begin{array}{c}\begin{array}{c}\text { udział } \\
\text { (w \%) }\end{array} \\
24,7\end{array}$} & \multirow{2}{*}{$\begin{array}{c}\text { kraj } \\
\text { Rosja }\end{array}$} & \multirow{2}{*}{$\begin{array}{c}\begin{array}{c}\text { udział } \\
\text { (w \%) }\end{array} \\
8,9\end{array}$} & \multirow{2}{*}{$\begin{array}{c}\text { kraj } \\
\text { Włochy }\end{array}$} & \multirow{2}{*}{$\begin{array}{c}\begin{array}{c}\text { udział } \\
\text { (w \%) }\end{array} \\
7,1\end{array}$} \\
\hline & Import & 101538,8 & & & & & & \\
\hline & Eksport & 89378,1 & Niemcy & 28,2 & Francja & 6,2 & Włochy & 6,1 \\
\hline \multirow[t]{2}{*}{2014} & Import & 225898,5 & Niemcy & 22,0 & Chiny & 10,4 & Rosja & 10,3 \\
\hline & Eksport & 222339,4 & Niemcy & 26,3 & Czechy & 6,5 & $\begin{array}{c}\text { Wielka Bryta- } \\
\text { nia }\end{array}$ & 6,4 \\
\hline
\end{tabular}

Źródło: [Rocznik Statystyczny Handlu Zagranicznego, 2014].

Jak wynika z dostępnych danych statystycznych zamieszczonych w tabeli 1., w okresie 2005-2014 nastąpił ponad dwukrotny wzrost obrotów handlowych Polski, a mianowicie: w imporcie o 122,5\%, a w eksporcie o 148,8\%. Głównym partnerem handlowym Polski zarówno w imporcie, jak i w eksporcie były i są Niemcy. Warto zauważyć, że pod względem wartości importu Chiny stały się drugim partnerem handlowym Polski. 
TABELA 2.

Przewozy ładunków w Polsce w latach 2004 i 2014, według liczby ton

\begin{tabular}{|l|r|r|r|r|c|}
\hline \multirow{2}{*}{ Wyszczególnienie } & \multicolumn{3}{|c|}{ Liczba ton (w tys.) } & \multicolumn{2}{c|}{$\begin{array}{c}\text { Podział między- } \\
\text { gałęziowy }\end{array}$} \\
\cline { 2 - 6 } & \multicolumn{1}{|c|}{2004} & 2014 & $\begin{array}{c}\text { Zmiana } \\
\text { (w \%) }\end{array}$ & $\mathbf{2 0 0 4}$ & $\mathbf{2 0 1 4}$ \\
\hline Transport ogółem & 1286,3 & 1840,0 & $+43 \%$ & $100,0 \%$ & $100,0 \%$ \\
Samochodowy & 957,0 & 1547,9 & $+62 \%$ & $74,4 \%$ & $84,1 \%$ \\
Kolejowy & 244,7 & 227,8 & $-7 \%$ & $19,0 \%$ & $12,4 \%$ \\
Rurociagowy & 53,4 & 49,8 & $-7 \%$ & $4,2 \%$ & $2,7 \%$ \\
Morski & 22,5 & 6,8 & $-70 \%$ & $1,7 \%$ & $0,4 \%$ \\
Żegluga śródlądowa & 8,7 & 7,6 & $-13 \%$ & $0,7 \%$ & $0,4 \%$ \\
Lotniczy & 0,03 & 0,04 & $+25 \%$ & $0,0 \%$ & $0,0 \%$ \\
\hline
\end{tabular}

Źródło: opracowanie własne na podstawie: [Transport-wyniki džiałalności..., 2005; Transportwyniki driatalności..., 2015].

Jak wynika z zamieszczonych danych, w analizowanym okresie wzrosła masa przewożonych ładunków o 43\%, przy czym w transporcie samochodowym wzrost przewozów wyniósł $62 \%$. Skutkiem tej tendencji był wzrost udziału transportu samochodowego w obsłudze potrzeb przewozowych z $74,4 \%$ do $84,1 \%$.

TABELA 3.

\section{Przewozy ładunków w Polsce w latach 2004-2014, według liczby tonokilometrów}

\begin{tabular}{|l|r|r|r|r|r|}
\hline \multirow{2}{*}{ Wyszczególnienie } & \multicolumn{2}{|c|}{ Liczba tkm (w mld) } & & \multicolumn{2}{c|}{$\begin{array}{c}\text { Podział } \\
\text { międzygałżziowy }\end{array}$} \\
\cline { 2 - 6 } & \multicolumn{1}{|c|}{$\mathbf{2 0 0 4}$} & $\mathbf{2 0 1 4}$ & $\begin{array}{c}\text { Zmiana } \\
\text { (w \%) }\end{array}$ & $\mathbf{2 0 0 4}$ & $\mathbf{2 0 1 4}$ \\
\hline Transport ogółem & 290 & 350 & $+20 \%$ & $100 \%$ & $100 \%$ \\
Samochodowy & 110,0 & 262,9 & $+139 \%$ & $37,8 \%$ & $75,2 \%$ \\
Kolejowy & 52,0 & 50,1 & $-4 \%$ & $17,9 \%$ & $14,3 \%$ \\
Rurociagowy & 25,0 & 22,1 & $-12 \%$ & $8,6 \%$ & $6,3 \%$ \\
Morski & 102,0 & 13,6 & $-87 \%$ & $35,1 \%$ & $3,9 \%$ \\
Żegluga śródlądowa & 1,1 & 0,78 & $-29 \%$ & $0,4 \%$ & $0,2 \%$ \\
Lotniczy & 0,09 & 0,15 & $+62 \%$ & $0,0 \%$ & $0,0 \%$ \\
\hline
\end{tabular}

Źródło: opracowanie własne na podstawie: [Transport- wyniki driałalności..., 2005; Transportmyniki driatalności..., 2015].

Zwiększony, europejski zasięg funkcjonowania polskiej gospodarki i działalności polskiego transportu spowodował wzrost średniej odległości przewozu jednej tony ładunku. Znalazło to odzwierciedlenie w znaczącym wzroście pracy przewozowej (liczba 
tonokilometrów), szczególnie w zakresie transportu samochodowego. Przy wzroście przewiezionej masy ładunków o 62\% nastąpił wzrost liczby tonokilometrów o blisko $140 \%$. W rezultacie zwiększył się udział transportu samochodowego w podziale międzygałęziowym z 37,8\% do 75,2\%.

Jednocześnie dynamiczny rozwój polskiego transportu samochodowego uwidocznił się w przewozach międzynarodowych w Unii Europejskiej. Udział polskich przewoźników w obsłudze tych przewozów, mierzony liczbą tonokilometrów, wzrósł z 8,9\% w 2005 roku do 24,3\% w 2013 roku, co dało Polsce pierwsze miejsce1. Było to możliwe dzięki niskim kosztom pracy polskich kierowców. Sytuacja ta spotyka się z brakiem akceptacji ze strony innych państw unijnych, co w ostatnim czasie skutkuje podejmowaniem różnych działań restrykcyjnych. Przykłady takich działań to wprowadzenie w Niemczech obowiązkowej stawki minimalnej płacy za godzinę (8,50 euro), obejmującej również kierowców firm transportowych spoza Niemiec, czy obowiązek spędzania tygodniowego odpoczynku kierowców w hotelu, a nie w kabinie pojazdu. Wdrożenie tego typu indywidualnych regulacji prawnych podważa jednak ideę wspólnego rynku, a to grozi zmniejszeniem efektywności transportu europejskiego i motywuje Komisję Europejską do podjęcia stosownych działań [Keynote speech..., 2016].

Znaczące zmiany zaszły również w podziale międzygałęziowym na rynku przewozów pasażerskich w Polsce. Tabele: 4. i 5. ilustrują zmiany w wielkości przewozów zrealizowanych transportem zbiorowym w poszczególnych gałęziach transportu.

TABELA 4.

Przewozy pasażerskie w Polsce transportem zbiorowym w 2004 i 2014 roku, według liczby pasażerów

\begin{tabular}{|l|r|r|r|r|r|}
\hline \multirow{2}{*}{ Wyszczególnienie } & \multicolumn{2}{|c|}{ Liczba pasażerów } & & \multicolumn{2}{c|}{ Struktura gałęziowa } \\
\cline { 2 - 6 } & \multicolumn{1}{|c|}{$\mathbf{2 0 0 4}$} & $\mathbf{2 0 1 4}$ & $\begin{array}{c}\text { Zmiana } \\
\text { (w \%) }\end{array}$ & \multicolumn{1}{c|}{$\mathbf{2 0 0 4}$} & \multicolumn{1}{c|}{$\mathbf{2 0 1 4}$} \\
\hline Transport ogółem & 1086,0 & 709,7 & $-35 \%$ & $100 \%$ & $100 \%$ \\
Samochodowy & 807,0 & 431,5 & $-46,5 \%$ & $74,3 \%$ & $60,8 \%$ \\
Kolejowy & 272 & 268,2 & $-1 \%$ & $25,0 \%$ & $37,8 \%$ \\
Morski & 0,6 & 0,61 & $+2 \%$ & $0,1 \%$ & $0,1 \%$ \\
Żegluga śródlądowa & 1,4 & 1,03 & $-26 \%$ & $0,1 \%$ & $0,1 \%$ \\
Lotniczy & 4,0 & 7,8 & $+95 \%$ & $0,4 \%$ & $1,1 \%$ \\
\hline
\end{tabular}

Źródło: opracowanie własne na podstawie: [Transport- wyniki driałalności..., 2005; Transportwyniki driatalności..., 2015].

Analizując dane w tabelach: 4. i 5. można zauważyć następujące tendencje:

- $\quad$ znaczący spadek liczby pasażerów przewożonych transportem zbiorowym;

- $\quad$ spadek liczby pasażerów przewożonych autobusami i busami o 46,5\%;

1 Obliczenia własne na podstawie: [EU Transport in Figures..., 2015, s. 35]. 
- $\quad$ stabilizacja liczby pasażerów podróżujących koleją dzięki regionalizacji i publicznemu dofinansowaniu przewozów kolejowych;

- dynamiczny rozwój transportu lotniczego; blisko dwukrotny wzrost liczby pasażerów i pracy przewozowej. Złożyły się na to: udostępnienie Polakom rynków pracy w Unii Europejskiej, wzrost zamożności i rozwój turystyki, jak również szeroka oferta przewozów lotnictwa niskokosztowego.

TABELA 5.

Przewozy pasażerskie w Polsce transportem zbiorowym w 2004 i 2014 roku, według liczby pasażerokilometrów

\begin{tabular}{|c|c|c|c|c|c|}
\hline \multirow{2}{*}{ Wyszczególnienie } & \multicolumn{2}{|c|}{ Liczba pas. km } & \multirow[b]{2}{*}{$\begin{array}{c}\text { Zmiana } \\
(\mathrm{w} \%)\end{array}$} & \multicolumn{2}{|c|}{$\begin{array}{l}\text { Struktura } \\
\text { gałęziowa }\end{array}$} \\
\hline & 2004 & 2014 & & 2004 & 2014 \\
\hline Transport ogółem & 56,0 & 51,4 & $-8 \%$ & 100 & 100 \\
\hline Samochodowy & 30,0 & 21,4 & $-29 \%$ & $53,6 \%$ & $41,6 \%$ \\
\hline Kolejowy & 18,7 & 16 & $-14 \%$ & $33,4 \%$ & $31,1 \%$ \\
\hline Morski & 0,17 & 0,148 & $-13 \%$ & $0,3 \%$ & $0,3 \%$ \\
\hline Żegluga śródlądowa & 0,02 & 0,129 & $+545 \%$ & $0,0 \%$ & $0,3 \%$ \\
\hline Lotniczy & 7,1 & 13,8 & $+94 \%$ & $12,7 \%$ & $26,8 \%$ \\
\hline
\end{tabular}

Źródło: opracowanie własne na podstawie: [Transport-myniki driatalhości..., 2005; Transport-uyniki driatalności..., 2015].

Spadek znaczenia zbiorowego transportu samochodowego wiąże się z rozwojem motoryzacji indywidualnej (dane w tabeli 6.). Nie jest to jednak zjawisko, które należy oceniać pozytywnie, ponieważ niejednokrotnie łączy się ono z brakiem dostępu do publicznej oferty transportowej w wielu mniejszych miejscowościach i regionach. Powoduje to wzrost uzależnienia od motoryzacji indywidualnej i wzrost zanieczyszczeń środowiska, wbrew przyjętej polityce zrównoważonego rozwoju.

TABELA 6.

Rozwój motoryzacji indywidualnej w Polsce, w latach 2005 i 2013

\begin{tabular}{|c|c|c|c|}
\hline \multicolumn{4}{|c|}{ Przewozy pasażerów w Polsce - motoryzacja indywidualna } \\
\hline Wyszczególnienie & 2005 & 2013 & $\begin{array}{c}\text { Zmiana } \\
(\mathrm{w} \%)\end{array}$ \\
\hline Liczba samochodów osobowych (w mln) & 12,339 & 19,389 & $+57 \%$ \\
\hline Praca przewozowa (w mld pas. km) & 152,3 & 213,1 & $+40 \%$ \\
\hline Wskaźnik motoryzacji* & 323 & 504 & $+56 \%$ \\
\hline Modal Split** (w \%) & 73,0 & 78,4 & \\
\hline
\end{tabular}

* Liczba samochodów osobowych przypadająca na 1000 mieszkańców.

** Udział pracy przewozowej wykonanej w motoryzacji indywidualnej w całości przewozów.

Źródło: opracowanie własne na podstawie: [EU Transport in Figures..., 2015]. 
Dane zebrane w tabelach wyraźnie pokazują umacnianie się roli transportu samochodowego w przewozach ładunków i w przewozach osób. Jest to szczególnie widoczne w odniesieniu do wskaźnika motoryzacji. W 2005 roku Polska, ze wskaźnikiem motoryzacji na poziomie 323 samochodów osobowych/1000 mieszkańców, zajmowała 24. miejsce wśród 28 państw Unii Europejskiej [EU Transport in Figures..., 2015]. W okresie ośmiu lat wskaźnik ten zwiększył swoją wartość do 504, a w ciąu tylko jednego roku (2014) osiagnął poziom 520 samochodów osobowych/1000 mieszkańców [EU Transport in Figures..., 2015]. Nastapił zatem nie tylko znaczacy wzrost wartości tego wskaźnika, ale Polska przesunęła się także na dużo wyższa, dziesiątą pozycję, którą zajęła na równi z Francja.

\subsection{Rozwój sieci drogowej}

Tak wyraźny wzrost udziału transportu samochodowego w obsłudze przewozów ładunków i pasażerów wynika zarówno ze zmian potrzeb gospodarki, jak i ze wzrostu zamożności oraz zmian możliwości i preferencji komunikacyjnych społeczeństwa. Sprzyja temu również dynamiczny rozwój infrastruktury drogowej, możliwy dzięki środkom pomocowym z Unii Europejskiej, co ilustruja dane zawarte w tabelach: 7. i 8.

TABELA 7.

Rozwój infrastruktury drogowej w Polsce, w latach 2005 i 2014

\begin{tabular}{|l|r|r|c|}
\hline \multicolumn{1}{|c|}{ Wyszczególnienie } & 2005 & 2014 & Zmiana (w \%) \\
\hline Drogi publiczne ogółem (w km) & 381463 & 417026 & $+9,3$ \\
Drogi publiczne o twardej nawierzchni (w km) & 253781 & 287650 & $+13,3$ \\
w tym drogi o nawierzchni ulepszonej & 227250 & 265160 & $+16,7$ \\
w tym - autostrady & 552 & 1556 & +182 \\
\multicolumn{1}{|c|}{ - drogi ekspresowe } & 258 & 1448 & +461 \\
\hline
\end{tabular}

Źródło: opracowanie własne na podstawie: [Transport- wyniki działalności..., 2006; Transportwyniki driałalności..., 2015].

Jak można zauważyć, największy wzrost miał miejsce w stosunku do długości dróg ekspresowych i autostrad. Trudno się temu dziwić, zważywszy poziom odniesienia. Mimo tego wyraźnego wzrostu, łącznie autostrady i drogi ekspresowe stanowią tylko około 1\% długości dróg o nawierzchni ulepszonej ogółem. Uwzględniając rosnący wskaźnik motoryzacji, wskazuje to na dalsze potrzeby zmian w wyposażeniu infrastrukturalnym kraju, które są wzmacniane przez oczekiwania użytkowników.

Bardziej miarodajne dla oceny stanu zagospodarowania infrastrukturalnego, niż bezwzględny wzrost długości sieci drogowych, są wskaźniki gęstości sieci. Wynika to ze znacznego zróżnicowania regionów Polski pod względem powierzchni i liczby ludności. Wzrost długości dróg, wykazany w tabeli 7., przekłada się na analogiczny wzrost gęstości geograficznej sieci ogółem w Polsce z 119,5 km/100km² do $132 \mathrm{~km} / 100 \mathrm{~km}^{2}$. Dane zawarte w tabeli 8. ilustrują zmiany gęstości sieci dróg o nawierzchni twardej i twardej ulepszonej w układzie regionalnym.

Najwyższy wskaźnik gęstości geograficznej sieci drogowej w 2005 roku charakteryzował województwa: śląskie, małopolskie i świętokrzyskie, zaś najmniejszy (wynoszący 
około jednej trzeciej wartości najwyższej) województwa: zachodniopomorskie, podlaskie i warmińsko-mazurskie.

Zmiana długości dróg publicznych o twardej nawierzchni z $253781 \mathrm{~km}$ (w 2005 roku) do $287650 \mathrm{~km}$ (w 2014 roku) spowodowała zmianę gęstości sieci drogowej z 81,2 do $92,0 \mathrm{~km} / 100 \mathrm{~km}^{2}$, tj. o $13 \%$. Trochę lepiej wypadła zmiana w gęstości dróg twardych o nawierzchni ulepszonej, z 72,7 do $84,8 \mathrm{~km} / 100 \mathrm{~km}^{2}$, tj. o $17 \%$. Największy wzrost gęstości dróg o nawierzchni twardej (o około $20 \%$ ) odnotowały województwa: mazowieckie, łódzkie, kujawsko-pomorskie i lubelskie. Natomiast gęstość dróg o nawierzchni twardej ulepszonej w największym stopniu (powyżej 20\%) wzrosła w województwach: podlaskim, mazowieckim, świętokrzyskim, łódzkim, kujawsko-pomorskim, podkarpackim.

Nie nastapiły jednak znaczące zmiany pod względem kolejności w rankingu. Województwa o najniższych wskaźnikach dróg, tj.: warmińsko-mazurskie, zachodniopomorskie, lubuskie, podlaskie, znalazły się na końcu tabeli i dzieliła je dość znaczna różnica w stosunku do kolejnej grupy województw o gęstości sieci powyżej $80 \mathrm{~km} / 100 \mathrm{~km}^{2}$. Częściowo można to wytłumaczyć warunkami geograficznymi, lecz dość niskie liczby procentowego przyrostu gęstości sieci wskazują na to, że podejmowane działania nie były wystarczające, aby zmniejszyć peryferyjność tych województw. Potwierdzeniem tej sytuacji jest niska dostępność transportowa województw Polski północnej i północno-wschodniej, oszacowana $z$ uwzględnieniem różnych gałęzi transportu na podstawie danych $z$ lat 2009-2010 (tabela 9.).

TABELA 8.

Wskaźnik geograficznej gęstości sieci drogowej w Polsce, w latach 2005 i $2014\left(\mathrm{w} \mathrm{km} / 100 \mathrm{~km}^{2}\right)$

\begin{tabular}{|c|c|c|c|c|c|c|c|}
\hline \multirow[t]{2}{*}{ Lp. } & \multirow[t]{2}{*}{ Województwa } & \multicolumn{2}{|c|}{$\begin{array}{c}\text { Drogi o nawierzchni } \\
\text { twardej }\end{array}$} & \multirow[t]{2}{*}{$\begin{array}{c}\text { Zmiana } \\
(\mathrm{w} \%)\end{array}$} & \multicolumn{2}{|c|}{$\begin{array}{l}\text { Drogi o nawierzchni } \\
\text { ulepszonej }\end{array}$} & \multirow[t]{2}{*}{$\begin{array}{c}\text { Zmiana } \\
(\mathrm{w} \%)\end{array}$} \\
\hline & & 2005 & 2014 & & 2005 & 2014 & \\
\hline & Ogółem w Polsce & 81,2 & 92,0 & +13 & 72,7 & 84,8 & +17 \\
\hline 1. & śląskie & 163,7 & 176,6 & +8 & 149,3 & 164,2 & +10 \\
\hline 2. & małopolskie & 144,3 & 160,3 & +11 & 123,2 & 145,1 & +18 \\
\hline 3. & świętokrzyskie & 103,2 & 117,7 & +14 & 82,8 & 102,6 & +24 \\
\hline 4. & dolnośląskie & 90,7 & 96,4 & +6 & 83,6 & 90,4 & +8 \\
\hline 5. & łódzkie & 90,5 & 109,4 & +21 & 81,7 & 100,7 & +23 \\
\hline 6. & opolskie & 88,9 & 89,1 & $+0,2$ & 78,8 & 83,0 & +5 \\
\hline 7. & wielkopolskie & 84,2 & 93,9 & +12 & 75,2 & 86,5 & +15 \\
\hline 8. & mazowieckie & 83,1 & 101,1 & +22 & 77,1 & 95,8 & +24 \\
\hline 9. & podkarpackie & 78,6 & 91,1 & +16 & 70,5 & 85,6 & +21 \\
\hline 10. & kujawsko- pomorskie & 78,5 & 94,4 & +20 & 68,0 & 83,6 & +23 \\
\hline 11. & lubelskie & 72,3 & 86,1 & +19 & 68,6 & 81,8 & +19 \\
\hline 12. & pomorskie & 62,9 & 71,0 & +13 & 57,8 & 64,8 & +12 \\
\hline 13. & lubuskie & 57,6 & 61,8 & +7 & 50,2 & 54,7 & +9 \\
\hline 14. & zachodniopomorskie & 55,6 & 60,2 & +8 & 50,5 & 54,7 & +8 \\
\hline 15. & podlaskie & 54,6 & 63,3 & +16 & 44,4 & 57,8 & +30 \\
\hline 16. & warmińsko-mazurskie & 51,1 & 54,6 & +7 & 47,5 & 50,7 & +7 \\
\hline
\end{tabular}

Źródło: opracowanie własne na podstawie: [Transport-wyniki driałalności..., 2006; Transport- wyniki driatalności..., 2015]. 
TABELA 9.

Dostępność transportowa województw

\begin{tabular}{|l|l|}
\hline $\begin{array}{c}\text { Dostępność } \\
\text { transportowa }\end{array}$ & \multicolumn{1}{c|}{ Województwa } \\
\hline A (bardzo dobra) & mazowieckie, śląskie, wielkopolskie \\
\hline B (dobra) & łódzkie, dolnośląskie, małopolskie, opolskie \\
\hline C (niska) & $\begin{array}{c}\text { świętokrzyskie, lubelskie, kujawsko-pomorskie, podkarpackie, } \\
\text { lubuskie, warmińsko-mazurskie, pomorskie }\end{array}$ \\
\hline D (bardzo niska) & zachodniopomorskie, podlaskie \\
\hline
\end{tabular}

Źródło: [Koźlak, 2012].

Zagospodarowanie infrastrukturalne jest jednym z istotnych elementów decydujących o możliwościach rozwoju kraju i regionów. O rozwoju infrastruktury transportu, ilościowym, jakościowym i przestrzennym decyduje nieodzowność zapewnienia wewnętrznej spójności i wspólpracy poszczególnych regionów. W tym kontekście należy stwierdzić, że w następstwie celowej polityki polskiej, wykorzystującej fundusze unijne, zaistniały pozytywne zmiany w rozwoju ilościowym i jakościowym infrastruktury drogowej we wszystkich województwach w Polsce. Jednak nie są one na tyle znaczące, aby przyczynić się do wyrównania wcześniejsze dysproporcje regionalne.

\section{Wyzwania wobec transportu wynikające $z$ jego roli w gospodarce i społeczeństwie}

Obsługa zwiększonych potrzeb przewozowych gospodarki i społeczeństwa oraz konieczność zwiększenia efektywności ekonomicznej i ekologicznej transportu wymagają nowoczesnych rozwiązań i nowych technologii w zakresie technicznego wyposażenia transportu. Jednym z priorytetów europejskiej polityki transportowej do 2030 roku jest zmniejszenie emisji gazów cieplarnianych o 60\%, co oznacza niezbędność opracowania nowych konstrukcji pojazdów, paliw alternatywnych i bardziej efektywnych systemów spalania. Problem jest o tyle poważny, że mimo wprowadzanych unormowań prawnych i wspierania zmian technologicznych, udział transportu w emisjach GHG od 1990 roku wzrósł z 15 do 22\% [Keynote speech..., 2016].

Wysokie wymagania wobec transportu, jego sprawności, kosztochłonności i niezawodności wynikają z oczekiwań jakościowych użytkowników transportu. W tym kontekście jest konieczne zwiększenie prędkości i bezpieczeństwa podróży, szybkości i częstotliwości dostaw oraz komfortu i odpowiedniej, multimodalnej informacji. W dużym stopniu zależy to od jakości i kompletności informacji oraz stosowanej technologii telekomunikacyjnej, dzięki której są tworzone zbiory danych. Jakość i sposób dostarczania informacji mają istotny wpływ na trafność podejmowanych decyzji przez operatorów transportu i użytkowników, umożliwiając modyfikację łańcuchów dostaw i podróży.

Wzrost potrzeb w zakresie mobilności i transportu w skali globalnej wymusza tworzenie nowych konstrukcji samolotów i statków o znacznie większych gabarytach, niż dotychczas, bardziej ekonomicznych, odpowiadających preferencjom klientów, a także 
spełniających wymagania ekologiczne. W konsekwencji istnieje konieczność dostosowania infrastruktury portów lotniczych do zwiększonego potoku pasażerów, a terminali cargo do zwiększonego obrotu towarowego. Taka sama potrzeba istnieje w odniesieniu do portów morskich. Aby porty mogły przyjać duże statki i odgrywać rolę centrów logistycznych, niezbędne są kompleksowe inwestycje, obejmujące również powiazania transportowe $\mathrm{z}$ zapleczem.

Stosunkowo nowym zjawiskiem, ale szybko osiagającym masową skalę, są migracje ludności, w tym uchodźców. Wielu ludzi jest zmuszonych opuścić swoje kraje z powodu: wojny, prześladowania, głodu itp. Przybywaja oni do krajów bogatszych, do Europy i do Polski, by uzyskać stosowną pomoc. Jednocześnie pomoc ta jest związana ze znacznym zaangażowaniem transportu. Ponadto, szczególnie w miastach, pojawia się potrzeba zapewnienia obsługi transportem publicznym dzielnic zamieszkałych przez ludzi, którzy nie mogą sobie pozwolić na własny samochód.

Nowe i duże wyzwania wobec transportu stawiają częste w ostatnim czasie katastrofy żywiołowe, takie jak: wielkie powodzie, trzęsienia ziemi, huragany czy pożary. Sytuacje takie wymagają skoordynowanej pomocy międzynarodowej. Potrzebne są inne niż zwykle środki transportu, np.: helikoptery, łodzie, a zarazem jest konieczna inna organizacja transportu pod katem ratowania ludzi i mienia w szybkim czasie. Jednym z dotkliwych skutków katastrof żywiołowych są zniszczenia sieci infrastruktury, w tym transportowej. Odbudowa i naprawa zniszczonej infrastruktury staje się podstawowym priorytetem, zmniejszając dostępną pulę środków na realizację innych zamierzeń rozwojowych infrastruktury.

System transportowy może sprzyjać rozwojowi gospodarki i wzrostowi jej efektywności, o ile zostana podjęte działania wychodzące naprzeciw przedstawionym wyzwaniom. Zmiany w transporcie, a zwłaszcza w infrastrukturze transportu wymagaja długoterminowego planowania. Dokumentem, który zawiera program działań w sektorze transportu w Polsce na najbliższych kilkanaście lat, jest „Strategia rozwoju transportu do 2020 roku" (z perspektywą do 2030 roku) przedstawiona w 2013 roku przez ówczesne ministerstwo do spraw transportu. W strategii wymieniono najważniejsze problemy. Są to:

- $\quad$ zwiększenie dostępności w czasie i w przestrzeni usług transportowych;

- ograniczenie kosztów i czasu transportu, przy jednoczesnej poprawie efektywności energetycznej i obniżeniu jednostkowych wskaźników emisyjności;

- rozwój multimodalności;

- $\quad$ spełnienie innych oczekiwań użytkowników.

Konsekwentnie jako główny cel krajowej polityki transportowej wskazano zwiększenie dostępności terytorialnej oraz poprawę bezpieczeństwa uczestników ruchu i efektywności sektora transportowego poprzez utworzenie spójnego, zrównoważonego i przyjaznego użytkownikowi systemu transportowego w wymiarze: krajowym (lokalnym), europejskim i globalnym. Jednym z priorytetów jest stworzenie spójnej sieci nowoczesnej infrastruktury obejmującej przede wszystkim połączenia kolejowe i drogowe pomiędzy głównymi miastami w kraju. Oznacza to konieczność: realizacji kapitałochłonnych i czasochłonnych inwestycji w infrastrukturę transportowa, przekształcenia systemu za- 
rządzania, a także wprowadzenia innowacyjnych (,inteligentnych”) rozwiązań ułatwiających funkcjonowanie tej infrastruktury w ramach całego systemu transportu oraz w wymiarze intermodalnym.

Powinno to służyć rozprzestrzenieniu się wzrostu gospodarczego silnych ośrodków na te części Polski, które z uwagi na brak dobrej dostępności terytorialnej pozostają obecnie w stagnacji. Jak wcześniej wspomniano w artykule, wiele obszarów w Polsce nie posiada jeszcze pożądanego poziomu dostępności transportowej. W efekcie powstają obszary wykluczenia społecznego, które nie wykorzystują zasobów kapitału ludzkiego, natomiast te w sytuacji dobrej dostępności terytorialnej mogłyby zostać zaktywizowane.

Jednak warto podkreślić, że warunkiem realizacji wymaganych inwestycji i wdrożenia zmian w systemie transportowym jest zapewnienie stabilnych źródeł ich finansowania, a zwłaszcza zbudowanie racjonalnego modelu finansowania inwestycji infrastrukturalnych (piąty cel szczegółowy strategii).

\section{Podsumowanie}

Włączenie Polski do procesu integracji europejskiej i coraz większy jej udział w globalnej gospodarce przekładają się na pewne widoczne trendy w polskim transporcie. Do najważniejszych zjawisk należy zaliczyć:

- dynamiczny wzrost międzynarodowego, pasażerskiego ruchu lotniczego i rozwój regionalnej infrastruktury lotniczej;

- umacnianie się roli transportu samochodowego w przewozach ładunków i osób, w tym znaczący wzrost towarowych przewozów samochodowych;

- gwałtowny rozwój motoryzacji indywidualnej przy jednoczesnym spadku znaczenia samochodowej komunikacji zbiorowej;

- zwiększenie roli połączeń transportowych w relacjach z Azja;

- $\quad$ wzrost potrzeb transportowych w obsłudze logistycznej dostaw;

- $\quad$ wzrost potrzeb przewozowych w miastach i aglomeracjach;

- rozwój ilościowy i poprawa jakości infrastruktury drogowej.

Reasumując, można stwierdzić, że tendencją wyróżniającą rozwój transportu w Polsce w ostatnich latach jest przede wszystkim istotny wzrost potrzeb przewozowych zarówno pod względem ilościowym, jak i w odniesieniu do standardów usług. Tym samym oznacza to, że sprawne i wydajne systemy transportowe, tanie i przyjazne środowisku, są warunkiem poprawy efektywności gospodarki. Aby transport był w stanie sprostać wymogom rozwoju gospodarczego oraz międzynarodowej współpracy i konkurencji, trzeba podjąć szereg działań o charakterze: technicznym, organizacyjnym i finansowym, jak też kulturowym i językowym. Chociaż obecnie stosowane rozwiązania techniczne w transporcie i logistyce w Polsce zapewniają stosunkowo wysoki poziom mobilności osób i transport towarów, umożliwiają szybkie i wygodne pokonywanie wielotysięcznych odległości, to nie są wystarczające do sprostania zadaniom stawianym w dobie postępującej globalizacji. Konieczne są zatem dalsze zmiany w infrastrukturze, 
w środkach transportu i standardach usług. Stąd szczególne znaczenie mają: szybkość realizacji przewozu, zapewnienie bezpieczeństwa transportu i dostęp do informacji.

\section{Wkład autorów w powstanie artykułu}

dr hab. inż. Anna Mężyk - współudział w opracowaniu koncepcji i założeń artykułu, zebranie danych, współudział w opracowaniu wyników - 50\%

dr hab. Stanisława Zamkowska - współudział w opracowaniu koncepcji i założeń artykułu , opracowanie części wstępnej, współudział w opracowaniu wyników - 50\%

\section{Literatura}

EU Transport in Figures. Statistical pocketbook 2015, www.ec.europa.eu (data wejścia: 25.04.2016).

Hryniewicz H., 2016, 33 tys. nowych samolotów do roku 2035?, „Polska Gazeta Transportowa", 20 lipca.

Keynote speech by Transport Commissioner Violeta Bulc at the 2016 Road Transport Conference, Bruksela, 19 kwietnia 2016.

Konwicki J., 2016, Dynamiczny wrorost polskiego rynku lotniczego, „Polska Gazeta Transportowa", 20 lipca.

Koźlak A., 2012, Nowoczesny system transportowy jako czynnik rozwoju regionów w Polsce, Wydawnictwo Uniwersytetu Gdańskiego, Gdańsk.

Plan utworzenia jednolitego europejskiego obszaru transportu - dażenie do osiagniecia konkurencyjnego $i$ zasobooszczednego systemu transportu, 2011, Biała Księga KOM(2011) 144 wersja ostateczna, Komisja Europejska, Bruksela.

Rocznik Statystyczny Handlu Zagranicznego, 2014, GUS, Warszawa.

Sobecki W., 2016, Dobre I pótroç̨e w portach w S zçecinie i Świnoujściu, „Polska Gazeta Transportowa", 10 sierpnia.

Strategia rozwoju transportu do 2020 roku (zperspektywa do 2030 roku), 2013, Ministerstwo Transportu, Budownictwa i Gospodarki Morskiej, Warszawa.

Transport - wyniki działalności w 2004 r., 2005 Główny Urząd Statystyczny, Warszawa. Transport - wyniki działalności w 2005 r., 2006 Główny Urząd Statystyczny, Warszawa. Transport- wyniki driatalności w 2014 r. - suplement, 2015, Główny Urząd Statystyczny, Warszawa.

Urbaniak J., Lotnicze cargo w Polsce - obiecujaco, choć bez fajerwerków, 2016, „Rynek Kolejowy", nr 5.

Wołodkiewicz-Donimirski Z., 2000, Podstawowe objawy globalizacji w światowej gospodarce, 7 Biuro Studiów i Ekspertyz - Kancelaria Sejmu RP, Warszawa. 